\title{
KEGIATAN PELAJAR MELAYU DI KAHERAH SEBELUM TAHUN 1970
}

\author{
Abu Hanifah Haris
}

\begin{abstract}
Malay students were among students from the Malay World who studied in Cairo, especially in the al-Azhar University since the late 19th century. This article discusses the activities of Malay students in Cairo before 1970, especially from First World War. This study shows that the Malay students in Cairo were involved in various social and political activities after the Second World War. Apart from establishing a good relationship with the Egyptian government, the Malay students in Cairo established relationships with student organizations from the Middle East, Africa and Southeast Asia. Malay students in Cairo also established a good relationship with the leaders of Malaya and the Malay rulers to ensure the welfare of Malay students in Cairo were addressed. A high sense of patriotism was also shown by the students in Cairo. They organized the celebration of the Independence Day of Malaya, as well as made recommendetions to the Malay Congress onmatters concerning the future of Malay rulers, the Malay states and the Malays. The Malay students in Cairo also welcomed the arrival of opposition leaders and leftist politicians who visited Cairo.
\end{abstract}

\section{Pengenalan}

Kaherah merupakan sebuah bandar di Mesir yang tidak asing bagi orang Melayu. Sejak akhir abad ke-19, Kaherah sudah muncul sebagai sebuah pusat pembelajaran ilmu agama yang terkenal dalam kalangan orang Melayu, sekali gus menarik minat ramai ibu bapa untuk menghantar anak mereka melanjutkan pengajian di sana. Tahun 1920-an pula merupakan kemuncak kepada kedatangan pelajar Melayu ke Kaherah 
yang menyaksikan jumlah pelajar Melayu yang menyambung pelajaran di Kaherah meningkat secara mendadak. Terdapat beberapa faktor dalam dan luaran yang menggalakkan kedatangan ramai pelajar Melayu ke Kaherah seperti peningkatan harga getah yang menyaksikan ramai ibu bapa berkemampuan untuk menghantar anak mereka menyambung pengajian di luar negeri, termasuklah Kaherah. Selain itu, suasana politik yang tidak stabil di Hejaz akibat peperangan yang tercetus antara Ibn Saud dan Syarif Husain menyebabkan Makkah tidak lagi menjadi tumpuan pelajar Melayu, selain peluang untuk mempelajari bidang politik yang terbuka luas di Kaherah.

Setakat ini banyak kajian tentang kegiatan pelajar Melayu di Kaherah lebih tertumpu kepada tempoh sebelum Perang Dunia Kedua sahaja. Hal ini menyebabkan maklumat tentang kegiatan pelajar Melayu di Kaherah selepas Perang Dunia masih kabur dan tidak jelas. Artikel ini cuba mengupas kegiatan yang dijalankan oleh pelajar Melayu yang menyambung pengajian di Kaherah khususnya di Universiti al-Azhar sebelum tahun 1970, khususnya selepas Perang Dunia Pertama. Secara umumnya, pelajar Melayu di Kaherah pernah terlibat dalam kegiatan bercorak sosial dan politik semasa belajar di sana. Sebelum Perang Dunia Kedua, pelajar Melayu di Kaherah bukan sahaja terlibat dalam kegiatan penerbitan dan percetakan buku dan kamus selain akhbar dan majalah Melayu, tetapi juga terlibat dalam kegiatan bercorak politik seperti menghadiri muktamar serta menjalinkan hubungan dengan parti politik dan tokoh politik Mesir.

\section{Kegiatan Pelajar Melayu di Kaherah Selepas Perang Dunia Pertama}

Selain menumpukan perhatian kepada pelajaran, pelajar Melayu di Kaherah juga terlibat dalam pelbagai kegiatan bercorak politik dan sosial. Dalam aspek sosial, pelajar Melayu di Kaherah pernah terlibat dalam kegiatan penerbitan dan percetakan buku dan kamus, selain akhbar dan majalah Melayu. Malah pelajar Melayu juga pernah menubuhkan syarikat percetakan sendiri di Kaherah. Syarikat percetakan pertama milik pelajar Melayu di Kaherah ialah Matbaah al-Ittihadiyyah yang telah ditubuhkan oleh Muhammad Fadlullah Suhaimi pada tahun 1914. ${ }^{1}$ Objektif utama penubuhan syarikat percetakan tersebut ialah mencetak majalah al-Ittihad. ${ }^{2}$ Penubuhan Matbaah al-Ittihadiyyah juga mempunyai perlembagaan yang tersendiri, iaitu terdiri daripada empat pasal yang mengandungi 30 perkara keseluruhannya. Antara matlamat penubuhan Matbaah al-Ittihadiyyah ialah bagi mencetak pelbagai jenis kitab dalam bahasa Arab, Melayu dan Jawa. Selain itu, penubuhannya juga bertujuan untuk mewujudkan cawangan kedai kitab di seluruh 
Alam Melayu. Matlamat penubuhan syarikat percetakan tersebut juga berkait rapat dengan cita-cita beliau untuk meluaskan pengedaran al-Ittihad. ${ }^{3}$ Selain mencetak al-Ittihad, satu-satunya karya lain yang diketahui pernah diterbitkan oleh Matbaah al-Ittihadiyyah ialah sebuah buku berjudul Kitab Pelajaran Tauhid yang telah diterbitkan pada tahun 1914. ${ }^{4}$ Kitab tersebut memuatkan perbincangan mengenai sifat Allah dan rasul-Nya yang disampaikan dalam bentuk soal jawab. Namun begitu, jangka hayat syarikat percetakan tersebut tidak bertahan lama setelah pemiliknya, Muhammad Fadlullah Suhaimi kembali ke Singapura pada akhir tahun 1914 setelah berjaya menamatkan pengajian di Universiti al-Azhar, Kaherah. ${ }^{5}$

Seorang lagi pelajar Melayu iaitu Muhammad Idris al-Marbawi bertanggungjawab menubuhkan Matbaah al-Marbawiyyah yang memulakan operasi pada tahun $1927 .{ }^{6}$ Matbaah al-Marbawiyyah pernah mencetak majalah Seruan Azhar untuk bilangan 30 dan bilangan 31. ${ }^{7}$ Antara kitab yang pernah dicetak oleh Matbaah al-Marbawiyyah yang terletak berhampiran Universiti al-Azhar ialah sebuah kitab karangan Shaykh Junid Tola yang berjudul Kitab Kaifiyat Mengadakan Wakaf yang diterbitkan pada tahun $1930 .{ }^{8}$ Matbaah al-Marbawiyyah juga pernah mencetak sebuah tulisan Shaykh Muhammad Tahir Jalaluddin berkaitan hukum solat sunat dua rakaat sebelum Jumaat. ${ }^{9}$ Sebuah lagi karya Melayu yang pernah dicetak oleh Matbaah al-Marbawiyyah ialah sebuah kamus berjudul Kamus al-Marbawi tulisan Muhammad Idris al-Marbawi. ${ }^{10}$ Kamus yang mempunyai hampir 18,000 perkataan ini mengandungi beratus-ratus gambar. Bagi memastikan kesahihan dan ketepatan isi kandungannya, kamus tersebut telah disemak oleh salah seorang ulama mazhab Syafii yang terkenal di Universiti al-Azhar iaitu al-Ustaz al-Fadil Aydul Wasif Muhammad. ${ }^{11}$

Pelajar Melayu di Kaherah juga telah menubuhkan sebuah lagi syarikat percetakan yang diberi nama Matbaah al-Taqaddum al-Ilmiyyah pada tahun 1927. ${ }^{12}$ Perusahaan utama yang dijalankan oleh Matbaah al-Taqaddum al-Ilmiyyah ialah mengendalikan urusan percetakan majalah Pilehan Timoer. ${ }^{13}$ Terdapat dua buah kitab tulisan Ahmad bin Abdul Latif yang pernah dicetak oleh Matbaah al-Taqaddum al-Ilmiyyah, iaitu kitab berjudul Izhar Zagl al-Khadibin fi Tasbih dan sebuah kitab berjudul al-Sa'if al-Battar fi Muhaq al-Kalimat $B a^{\prime} d$ Ahl alIstighrar. ${ }^{14}$

Pelajar Melayu juga pernah terlibat dalam pelbagai kegiatan bercorak politik semasa melanjutkan pelajaran di Kaherah. Namun begitu, seorang bekas pelajar Melayu di Kaherah pernah menyatakan bahawa majoriti pelajar Melayu di Kaherah tidak terlibat dalam kegiatan politik semasa belajar di sana. ${ }^{15}$ Seorang lagi bekas pelajar Melayu di Kaherah pula berpendapat bahawa meskipun segelintir pelajar Melayu 
terdedah dengan perkembangan politik Mesir, namun kebanyakan mereka lebih berminat untuk memajukan diri dalam bidang akademik ketika belajar di Kaherah. ${ }^{16}$ Bahkan terdapat bekas pelajar Melayu di Kaherah yang menegaskan bahawa kebanyakan pelajar Melayu di Kaherah yang cemerlang dari sudut akademik seterusnya dilantik sebagai mufti atau kadi setelah pulang ke tanah air tidak terlibat dalam kegiatan politik. ${ }^{17}$ Walaupun majoriti pelajar Melayu tidak terlibat secara langsung dalam kegiatan politik, namun terdapat pelajar Melayu yang terlibat dalam kegiatan politik di Kaherah, seterusnya mempengaruhi kesedaran politik dalam kalangan masyarakat setelah pulang ke tanah air.

Pendedahan kepada perkembangan politik di Kaherah juga menjadi salah satu sebab pelajar Melayu memilih untuk menyambung pengajian di Kaherah berbanding Makkah. Salah seorang lepasan Universiti al-Azhar iaitu Othman Abdullah pernah menyatakan bahawa beliau memilih untuk belajar di Kaherah kerana seseorang hanya dapat mempelajari agama di Makkah, sebaliknya di Kaherah mereka juga dapat mempelajari politik. ${ }^{18}$ Harun Nasution juga merupakan antara pelajar Melayu yang terdedah kepada kegiatan politik semasa belajar di Kaherah. Menurut beliau, pelajar Melayu yang menyambung pelajaran di Kaherah mempunyai pemikiran yang moden berbanding mereka yang belajar di Makkah. Beliau bukan sahaja berpendapat bahawa Kaherah merupakan pusat kegiatan politik, malah beliau sendiri pernah berhubung dengan pemimpin politik Mesir daripada Parti Wafd, Misr al-Fatat dan Ikhwan al-Muslimin. ${ }^{19}$

Penganjuran Perhimpunan Islam yang diadakan di Surabaya, Indonesia pada tahun 1926 turut dilaporkan oleh majalah al-Manar. Pada 5 November 1926, majalah al-Manar menyiarkan tulisan Sayyid Abdullah bin Salim al-Attas yang berkesempatan menghadiri Perhimpunan Khalifah yang diadakan pada 20 September 1926. Meskipun kerajaan Belanda di Indonesia berusaha untuk menghalang penganjuran perhimpunan tersebut, namun perhimpunan tersebut masih dihadiri oleh ratusan hadirin yang terdiri daripada golongan belia dan hampir 40 buah pertubuhan Islam dari seluruh Indonesia, sekali gus mendapat liputan yang meluas daripada akhbar utama di Indonesia. Antara tokoh yang menyampaikan ucapan dalam perhimpunan tersebut ialah Haji Omar Said Tjokroaminoto dan Haji Mansur. ${ }^{20}$ Antara usul yang telah dipersetujui dalam perhimpunan tersebut ialah pembentukan panitia khusus bagi memudahkan urusan pengerjaan haji bagi masyarakat Melayu, pemansuhan Perhimpunan Khalifah dan pembentukan Perhimpunan Islam Hindia Timur, pembentukan Jawatankuasa Pelaksana bagi Perhimpunan Islam Hindia Timur yang berpusat di Surabaya, dan pengumpulan dana berjumlah $£ 900$ bagi membiayai 
penganjuran Perhimpunan Islam yang akan diadakan di Makkah pada tahun yang akan datang. ${ }^{21}$

Selain menyuarakan doktrin politik mereka tentang kebebasan dan kemerdekaan melalui penyiaran rencana yang disiarkan dalam Seruan Azhar dan Pilehan Timoer, pelajar Melayu juga memanifestasikan kesedaran politik mereka melalui persatuan yang mewakili pelajar Melayu di Kaherah iaitu al-Jamiyyah al-Khairiyyah al-Talabiyyah alAzhariyyah al-Jawah. ${ }^{22}$ Pada tahun 1926, al-Jamiyyah al-Khairiyyah telah menghantar Djanan Taib sebagai delegasi persatuan ke Muktamar Islami yang dianjurkan oleh Ibn Saud di Makkah ketika musim haji bagi tahun tersebut. Ketika tercetusnya konflik antara imigran Yahudi dengan penduduk Arab di Jurusalem (Bayt al-Muqaddis), Presiden al-Jamiyyah al-Khairiyyah iaitu Haji Abu Bakar Ashaari dan wakil persatuan iaitu Abdul Kahar Muzakkir tiba di Palestin bagi menyuarakan pandangan mereka untuk mempertahankan Kota Suci tersebut. Ketika berlangsungnya Persidangan Umum Islam di Palestin pada tahun 1931 yang dianjurkan oleh Mufti Jurusalem, Abdul Kahar Muzakkir telah dilantik sebagai Setiausaha bagi sebuah organisasi yang baru dibentuk iaitu Muktamar Alam Islami. ${ }^{23}$

Pelajar Melayu di Kaherah juga mempunyai hubungan yang rapat dengan pertubuhan dan pemimpin politik Mesir, khususnya Hizb al-Watani (Parti Nasionalis). Melalui al-Jamiyyah al-Khairiyyah, pelajar Melayu bukan sahaja menjalinkan hubungan dengan pemimpin Hizb al-Watani seperti Mustafa Kamil dan Muhammad Farid, bahkan turut menghadiri majlis memperingati kematian mereka berdua pada 30 Disember 1926. ${ }^{24}$ Kematian seorang tokoh pemimpin al-Hizb alWatani iaitu Ali Fahmi pula menyaksikan pelajar Melayu bukan sahaja menghadiri majlis pengebumian beliau, bahkan turut melaporkan sejarah hidup dan perjuangan beliau dalam Seruan Azhar. ${ }^{25}$ Pelajar Melayu di Kaherah juga mempunyai hubungan yang rapat dengan seorang lagi pemimpin Mesir iaitu Shaykh Abdul Aziz Jawish kerana sifat prihatin beliau yang sering membantu pelajar Melayu di Kaherah. Selain Hizb al-Watani, pelajar Melayu di Kaherah juga mempunyai hubungan yang rapat dengan tokoh politik Mesir yang lain seperti bekas Perdana Menteri Mesir, Saad Zaghlul, Abdul Aziz Affendi Suhaimi dan Shaykh al-Majid al-Ban. ${ }^{26}$

Terdapat juga ulama Tanah Melayu juga menjadikan tokoh pemimpin Mesir sebagai contoh terbaik bagi melaksanakan perubahan dan pembaharuan dalam masyarakat secara lebih efektif dan efisien. Haji Wan Musa bin Haji AbdulSamad, bekas Mufti Kelantan (1908-1916) merupakan salah seorang ulama yang cuba mencontohi pendekatan yang dilakukan oleh pemimpin Mesir bagi melaksanakan perubahan. ${ }^{27}$ Bagi menghapuskan amalan bidaah dan sistem feudal yang masih 
dipertahankan oleh golongan bangsawan sehingga menghalang mereka daripada menyediakan peluang pendidikan dan menjaga kebajikan rakyat jelata, Haji Wan Musa telah mengambil contoh kehidupan rakyat Mesir di bawah kepimpinan Mustafa Kamil, seorang tokoh kebangsaan Mesir. ${ }^{28}$ Perasaan kagum Haji Wan Musa terhadap kepimpinan Mustafa Kamil dan kemajuan rakyat Mesir bukanlah sesuatu yang luar biasa kerana beliau sendiri gemar membaca majalah al-Urwah al-Wuthqa dan al-Manar, selain merujuk Tafsir Tantawi al-Jawhari tulisan seorang ulama al-Azhar yang terkenal iaitu Shaykh Tantawi al-Jawhari. ${ }^{29}$

\section{Kegiatan Pelajar Melayu di Kaherah Selepas Perang Dunia Kedua}

Secara umumnya, orang Melayu melihat bahawa Mesir sebagai salah sebuah negara Islam yang mencapai kemajuan tanpa meninggalkan syiar Islam sehingga menyebabkan segelintir masyarakat Melayu mencadangkan agar kerajaan Tanah Melayu mencontohi kemajuan yang dicapai oleh Mesir, termasuklah dalam penggubalan bendera kebangsaan yang menonjolkan identiti dan lambang sesebuah negara. Pada tahun 1949, seorang pembaca Melayu pernah mencadangkan agar lambang bulan sabit dan bintang perlu dimasukkan dalam bendera Persekutuan Tanah Melayu yang akan dihasilkan kelak agar menyerupai bendera beberapa negara Islam yang lain, termasuklah Mesir. ${ }^{30}$

Selepas Perang Dunia Kedua, orang Melayu juga terus menunjukkan minat yang mendalam terhadap perkembangan politik yang berlaku di Kaherah. Pada 5 Jun 1948, Kuliyyah al-Lughah wa al-Din Sultan Abu Bakar di Pekan, Pahang dilaporkan menganjurkan Majlis Sambutan Israk Mikraj di kolej tersebut. Salah satu acara yang akan diadakan dalam majlis tersebut ialah penyerahan gambar raja Mesir, Raja Faruq kepada Sultan Pahang. ${ }^{31}$ Pada tahun 1965, sebuah ceramah yang disampaikan kepada ahli Persatuan Melayu Pulau Pinang berkenaan perkembangan sejarah dan politik Mesir bertajuk "Mesir Dahulu dan Sekarang" juga mendapat sambutan yang menggalakkan. ${ }^{32}$ Ceramah tersebut telah disampaikan oleh Sayyid Ali, seorang bekas pensyarah Universiti al-Azhar yang bertugas di Madrasah al-Masyhur, Pulau Pinang. ${ }^{33}$

Pendedahan terhadap perkembangan politik Mesir juga telah mengajar pelajar-pelajar Melayu di Kaherah agar mewujudkan hubungan yang akrab dengan pemimpin Mesir bagi memastikan permasalahan yang dihadapi oleh pelajar Melayu mendapat perhatian daripada pemerintah Mesir. Hubungan akrab antara pelajar Melayu yang diwakili oleh Persekutuan Melayu Mesir (PMM) dengan Presiden Mesir, Gamal Abdel Nasser dapat dilihat melalui ucapan yang disampaikan oleh PMM, 
diikuti ucapan balas Presiden Nasser sempena sambutan sesuatu majlis. Pada 19 Februari 1962, Yang Dipertua PMM iaitu Abdul Kadir Talib telah menghantar telegram kepada Presiden Nasser bagi mengucapkan takziah atas kematian Salah Salim, Menteri Perpaduan Negara UAR (Mesir). ${ }^{34}$ Sempena sambutan Hari Raya Aidiladha pada tahun 1962, PMM juga telah menghantar telegram sebagai tanda ingatan kepada Presiden Nasser. ${ }^{35}$

Pada 15 Disember 1962, seorang pelajar Melayu di Universiti alAzhar iaitu Jaafar Hassan telah menerima hadiah daripada Presiden Nasser setelah muncul sebagai salah seorang pelajar terbaik Fakulti Usuluddin dalam peperiksaan akhir tahun. Hadiah tersebut disampaikan kepada beliau sempena sambutan Hari Ilmu Pengetahuan yang diadakan di Balai Kemerdekaan, Kaherah. ${ }^{36}$ Sempena pengisytiharan Mesir sebagai anggota United Arab Republic (UAR), Yang Dipertua PMM juga telah menghantar ucapan tahniah kepada Presiden Nasser pada 18 April 1963. ${ }^{37}$ Sempena kedatangan Hari Raya Aidilfitri pada tahun 1963, PMM juga telah menghantar telegram bagi mengucapkan Selamat Hari Raya Aidilfitri kepada Presiden Nasser dan seluruh rakyat UAR, seterusnya mengucapkan terima kasih atas perhatian dan bantuan yang telah diberikan kepada PMM dan pelajar Melayu. ${ }^{38}$ Pada bulan Jun 1963, Yang Dipertua PMM, Abu Bakar Haji Mohammad telah menghantar telegram kepada Presiden Nasser sempena Hari Raya Aidiladha. Presiden Nasser turut membalas telegram tersebut dan mengucapkan terima kasih atas ingatan seluruh pelajar Melayu dan PMM yang sudi memberikan ucapan selamat kepada beliau. ${ }^{39}$

Bagi memastikan urusan pelajar Melayu di Universiti al-Azhar berjalan lancar, pelajar Melayu di Kaherah turut menjalinkan hubungan dengan Menteri Wakaf dan Urusan al-Azhar yang mengendalikan pengurusan al-Azhar dan Rektor Universiti al-Azhar. Sempena sambutan Hari Raya Aidiladha pada tahun 1962, PMM memberikan ucapan selamat kepada Rektor Universiti al-Azhar, Shaykh Mahmud Shaltut. ${ }^{40}$ Pada 5 Oktober 1962, Yang Dipertua PMM telah menghantar telegram kepada Dr. Muhammad Bahai bagi mengucapkan tahniah sempena pelantikan beliau sebagai Menteri Wakaf dan Urusan al-Azhar dan berharap agar beliau dapat memajukan lagi pentadbiran Universiti al-Azhar. ${ }^{41}$ Sempena sambutan Hari Raya Aidilfitri pada tahun 1963, PMM telah menghantar telegram bagi mengucapkan Selamat Hari Raya Aidilfitri kepada Rektor Universiti al-Azhar, Shaykh Mahmud Shaltut dan Menteri Wakaf dan Urusan al-Azhar, Dr. Muhammad Bahai. ${ }^{42}$ PMM juga turut menghantar telegram sempena kedatangan Hari Raya Aidiladha pada tahun 1963 kepada Menteri Wakaf dan Urusan al-Azhar, Dr. Muhammad Bahai. ${ }^{43}$

Selain pihak pengurusan tertinggi Universiti al-Azhar, PMM turut menjalinkan hubungan dengan sekolah atau kolej yang bernaung 
di bawah Universiti al-Azhar. Pada bulan Oktober 1962, PMM turut menghantar telegram bagi mengucapkan tahniah sempena pelantikan beberapa individu sebagai pengetua sekolah dan kolej seperti pelantikan Dr. Aishah Abdul Rahman sebagai Pengetua Kulliyyah al-Banat di Kaherah, pelantikan Insaf Junaydi sebagai Pengetua Maahad li alFatayah di Kaherah dan pelantikan Muhammad Hasan Shabanah sebagai Pengetua Maahad al-Azhar di Kaherah. ${ }^{44}$ Hubungan yang baik juga terjalin antara pelajar Melayu di Kaherah dengan Kementerian Kebajikan Masyarakat UAR. Pada 26 Januari 1963, Yang Dipertua PMM pernah mengadakan lawatan ke Kementerian Kebajikan Masyarakat UAR di Mujamma'. ${ }^{45}$

Pelajar Melayu di Kaherah juga mempunyai hubungan yang baik dengan Majlis Agama Islam di Mesir. Pada bulan Jun 1963, wakil PMM telah membawa Kadi Kedah, Shaykh Abdul Aziz Ahmad dan Pesuruhjaya Persatuan Seruan Islam Seluruh Tanah Melayu Cawangan Pulau Pinang, Yusuf Rawa bagi menemui Setiausaha Majlis Tertinggi Urusan Agama Islam Mesir. Setiausaha majlis bukan sahaja kagum dengan perkembangan Islam di Tanah Melayu, bahkan telah mendermakan masing-masing 10,000 naskhah al-Quran dan 5,000 buah kitab yang diterbitkan oleh majlis tersebut kepada mereka berdua. ${ }^{46}$

Hubungan erat juga terjalin antara pelajar Melayu di Kaherah dengan pertubuhan pelajar di Mesir. Pada 1 April 1962, Yang Dipertua PMM telah menghadiri persidangan pelajar di daerah Qalyub, Mesir atas jemputan Persekutuan Pelajar-Pelajar UAR. Yang Dipertua PMM juga telah mengambil kesempatan tersebut untuk memberikan cenderamata kepada peserta persidangan tersebut yang terdiri daripada pelbagai lapisan masyarakat seperti golongan pendidik, para pelajar dan ahli persatuan. ${ }^{47}$ Pada bulan Mei 1962, penglibatan aktif PMM sebagai salah sebuah persatuan pelajar asing yang aktif di Kaherah juga menyebabkan Idarah al-Wafidin yang menguruskan pertubuhan pelajar di Mesir bersetuju untuk memberikan bantuan kewangan sebanyak $£ 50$ (Mesir) kepada PMM. ${ }^{48}$

Pada 24 April 1962, Yang Dipertua PMM telah menghantar Abu Bakar bin Mohd. Nor bagi mewakili PMM dalam perjumpaan pelajarpelajar daerah Asyut, Mesir. ${ }^{49}$ Pada 23 Julai 1962, PMM telah menghantar ucapan tahniah kepada Persatuan Pelajar-Pelajar UAR sempena sambutan Hari Pemberontakan UAR. ${ }^{50}$ Pada bulan November 1962, PMM juga telah melantik wakil khas bagi memberi ceramah berkenaan Tanah Melayu pada bila-bila masa atas permintaan Idarah al-Wafidin. ${ }^{51}$ Pada 20 Februari 1963, wakil PMM juga telah menghadiri Majlis Berbuka Puasa anjuran Persatuan Pelajar-Pelajar UAR yang diadakan di Hotel Umayyah, Kaherah. Wakil PMM juga turut menghadiri Majlis Berbuka 
Puasa anjuran Nadi al-Wafidin yang berlangsung di pejabat Kelab Polis UAR. ${ }^{52}$

Hubungan yang baik juga terjalin antara pelajar Melayu di Kaherah dengan negara-negara Timur Tengah dan Afrika yang lain. Pada 18 Julai 1962, PMM telah menghadiri sambutan ulang tahun Pemberontakan Oman di pejabat Persatuan Wartawan UAR. ${ }^{53}$ Sempena Hari Kemerdekaan Uganda, Naib Setiausaha Agong iaitu Md. Taib Hassan telah mewakili PMM bagi menghadiri sambutan Hari Kemerdekaan Uganda yang diadakan di Nadi Tala'at Harb di Ambabah. ${ }^{54}$ Pada 31 Oktober 1962, Yang Dipertua PMM dan Setiausaha Agong PMM telah menghadiri sambutan ulang tahun Pemberontakan Algeria. Pada 25 November 1962, Yang Dipertua PMM juga telah menghadiri majlis sambutan sempena ulang tahun Hari Kemerdekaan Sudan. ${ }^{55}$

Pelajar Melayu di Kaherah juga berusaha untuk mengukuhkan hubungan serantau dengan pertubuhan pelajar yang mewakili pelajar dari Tanah Melayu di Timur Tengah, khususnya pertubuhan pelajar Melayu di Makkah. Pada 10 November 1962, PMM telah menerima surat daripada Gabungan Pelajar-Pelajar Melayu Semenanjung (GAPES) mewakili pelajar Melayu di Makkah yang berharap agar perhubungan erat antara kedua-dua pihak yang telah terjalin sebelum ini akan terus berkekalan. ${ }^{56} \mathrm{Hal}$ ini membuktikan bahawa pertubuhan pelajar Melayu di Kaherah tidak hanya menjaga kebajikan pelajarnya, bahkan turut mengambil berat terhadap kebajikan pelajar Melayu lain yang turut menuntut ilmu di Timur Tengah, khususnya di Makkah.

Peluang belajar di Kaherah juga memberi peluang kepada pelajar Melayu untuk menjalinkan hubungan awal dengan negara serantau di Asia Tenggara selepas Tanah Melayu mencapai kemerdekaan, iaitu melalui penglibatan mereka dalam program yang dianjurkan oleh pelajar dari Asia Tenggara di Kaherah atau sambutan yang diberikan kepada pemimpin Asia Tenggara yang melawat Mesir. Bahkan pelajar Melayu di Kaherah juga telah mengadakan hubungan dan kerjasama dengan pelajar Asia Tenggara jauh lebih awal sebelum penubuhan ASEAN lagi, khususnya melalui jemputan kepada pelajar Filipina, Thailand, Singapura dan Brunei bagi menghadiri majlis dan aktiviti anjuran PMM. ${ }^{57}$

Pada 4 Februari 1962, Yang Dipertua PMM iaitu Abdul Kadir Talib telah menghadiri sambutan ulang tahun kemerdekaan Indonesia anjuran Persatuan Pelajar-Pelajar Indonesia. ${ }^{58}$ Pada 25 April 1962, Yang Dipertua PMM dan Setiausaha PMM bersama-sama pelajar dari Singapura telah menyambut ketibaan Perdana Menteri Singapura, Lee Kuan Yew. Pada 28 April 1962, Badan Kebajikan PMM telah mengadakan majlis sambutan sempena kedatangan Lee Kuan Yew ke Mesir. ${ }^{59}$ Pada bulan Ogos 1962, Yang Dipertua PMM bukan sahaja bersetuju untuk menghadiri sambutan Hari Kemerdekaan Indonesia yang dianjurkan oleh Persatuan Pelajar- 
Pelajar Indonesia di Mesir, bahkan turut bersetuju untuk memberikan ucapan dalam majlis sambutan tersebut. ${ }^{60}$

Bagi mengeratkan silaturahim antara pelajar Asia Tenggara, Badan Pengetahuan PMM juga telah menganjurkan Peraduan Membaca alQuran yang terbuka kepada pelajar dari Tanah Melayu, Indonesia, Thailand dan Filipina pada 30 Ogos 1962. ${ }^{61}$ Pada 28 Oktober 1962, Yang Dipertua PMM telah menghadiri sambutan ulang tahun Sumpah Pemuda Indonesia Ke-34 di pejabat Persatuan Pelajar-Pelajar Indonesia. ${ }^{62}$ Pada 8 Disember 1962, Yang Dipertua PMM telah menghadiri ceramah yang telah disampaikan oleh seorang sarjana ekonomi dari Indonesia anjuran Persatuan Pelajar-Pelajar Indonesia. ${ }^{63}$ Pada 12 Februari 1963, Naib Yang Dipertua PMM juga telah menghadiri majlis sambutan Nuzul al-Quran anjuran bersama Kedutaan Indonesia dan Persatuan Pelajar-Pelajar Indonesia bertempat di Kedutaan Indonesia, Kaherah. ${ }^{64}$ Pada 30 Jun 1963, Yang Dipertua PMM telah menghadiri program anjuran Sekolah Indonesia di Dokki, Mesir. ${ }^{65}$

Kesedaran politik dalam kalangan pelajar Melayu di Kaherah juga dapat dilihat melalui usaha yang telah dijalankan oleh Persekutuan Putera-Putera Semenanjung (PPS) dan PMM bagi mengeratkan hubungan dengan para pemimpin Tanah Melayu, khususnya menteri kabinet dan pegawai kerajaan Tanah Melayu. PPS misalnya pernah menyambut ketibaan Tengku Mahmud Mahyiddin, seorang pegawai kerajaan yang melawat Kaherah pada bulan Januari 1944, dan telah menyambut kedatangan Tengku Mahmud Mahyiddin sekali lagi pada bulan Februari 1945. ${ }^{66}$ PPS juga telah menyambut ketibaan Dato' Laksamana Perak, Muhammad Razali yang telah melawat Mesir pada bulan Jun 1949. ${ }^{67}$

Pada 26 Mac 1962, PMM telah mengadakan majlis sambutan sempena lawatan Menteri Pertanian dan Koperasi, iaitu Abdul Aziz Ishak ke pejabat PMM. ${ }^{6}$ Pada 1 Mac 1962, Yang Dipertua PMM telah menziarahi Penolong Pengarang, Dewan Bahasa dan Pustaka (DBP) iaitu Othman Sulaiman di Hotel Jazirah Palace, Kaherah seterusnya menerima lawatan Pegawai Pejabat Pelajaran Johor, Mohammad Ahmad di pejabat PMM pada 6 Mac 1962. ${ }^{69}$ Pada 13 April 1962, Pengarah DBP telah menemui Yang Dipertua PMM bagi membincangkan kegiatan PMM dan keadaan pelajar Melayu di Kaherah. Pada 14 April 1962, PMM telah menyambut kedatangan Syed Nasir Ismail, pemimpin UMNO dari Johor. ${ }^{70}$

Pada 6 Mei 1962, wakil PMM telah menyambung kedatangan Sardon Zubir dan isteri serta rombongan Sultan Brunei yang melawat Kaherah, diikuti sambutan terhadap kedatangan Duta Tanah Melayu ke Arab Saudi yang tiba di Kaherah pada 29 Mei 1962. Wakil PMM juga menyambut kedatangan Menteri Pelajaran Tanah Melayu di Lapangan Terbang Kaherah pada 1 Mei 1962. ${ }^{71}$ Pada 6 Jun 1962 pula, PMM telah 
menerima lawatan Pengetua Maktab Perguruan Bahasa iaitu Lokman Musa di pejabat PMM. Sebelum itu, PMM telah menghantar telegram kepada Pengetua Kolej Islam Malaya, Abdul Jalil Hassan sempena kematian isteri beliau pada 4 Jun 1962. Pada 14 Julai 1962, Yang Dipertua PMM telah menyambut ketibaan Timbalan Perdana Menteri, Abdul Razak, diikuti Perdana Menteri, Tunku Abdul Rahman di Lapangan Terbang Kaherah pada 16 Julai $1962 .{ }^{72}$

Pada 8 November 1962, PMM telah menghantar surat kepada Kapten Abdul Hamid Khan sempena pelantikan beliau sebagai Menteri Pelajaran. ${ }^{73}$ Pada 29 November 1962, Yang Dipertua PMM telah menyambut ketibaan Timbalan Menteri Perdagangan dan Industri di Lapangan Terbang Kaherah. ${ }^{74}$ Pada 16 Februari 1963, wakil PMM telah menyambut ketibaan Othman Abdullah, seorang Ahli Dewan Undangan Negeri (ADUN) di Tanah Melayu di Lapangan Terbang Kaherah. ${ }^{75}$ Pada 27 Februari 1963, wakil PMM telah menemui Othman Abdullah bagi menyampaikan pesanan PMM, seterusnya menyerahkan senarai anggota PMM kepada beliau pada 2 Mac 1963. ${ }^{76}$ Pada 13 Mei 1963, Yang Dipertua PMM telah menyambut ketibaan rombongan Menteri Besar Terengganu di kediaman Duta Tanah Melayu di Mesir. Pada 17 Mei 1963, Yang Dipertua PMM telah menyambut ketibaan Menteri Besar Melaka di Lapangan Terbang Kaherah. ${ }^{77}$ Pada 10 Julai 1963, Yang Dipertua PMM telah menemui Timbalan Perdana Menteri, Abdul Razak bagi membincangkan beberapa perkara berkaitan perasmian Rumah Melayu di Kaherah. ${ }^{78}$

Pelajar Melayu di Kaherah juga mempunyai hubungan yang baik dengan negeri-negeri Melayu. Hubungan yang erat antara PMM dengan kerajaan Terengganu misalnya dapat dilihat pada kesudian Yang Dipertua PMM menghantar surat kepada Pesuruhjaya Hal Ehwal Agama Terengganu bagi memaklumkan keadaan dan kebajikan pelajar Terengganu di Kaherah pada 4 Disember $1962 .{ }^{79}$ Surat sama yang memaklumkan keadaan pelajar Terengganu di Kaherah juga pernah dihantar oleh Yang Dipertua PMM kepada Pesuruhjaya Hal Ehwal Agama Terengganu pada 1 Februari 1963. ${ }^{80}$

Pelajar Melayu di Kaherah juga mempunyai hubungan yang erat dengan raja-raja Melayu. Pada bulan Ogos 1950, PPS pernah menyambut kedatangan Sultan Pahang yang melawat pelajar Melayu di Kaherah. ${ }^{81}$ Pada 8 Jun 1962, Yang Dipertua PMM telah menemui ipar kepada Yang di-Pertuan Agong, Tunku Abdul Rahman di Hotel Victoria, Kaherah. ${ }^{82}$ Pada 31 Mei 1963, Yang Dipertua PMM telah menyambut kedatangan rombongan Sultan Kedah di Lapangan Terbang Kaherah. ${ }^{83}$ Sempena lawatan tersebut, Sultan Kedah juga bermurah hati untuk mendermakan sebanyak $£ 50$ (Mesir) kepada Tabung Derma Pelajaran PMM, manakala sebuah piala berharga $£ 25$ (Mesir) pula telah dihadiahkan kepada Badan 
Sukan dan Perkelahan PMM sebagai hadiah bagi Kejohanan Bola Sepak anjuran PMM. ${ }^{84}$ Pada 1 Jun 1963, Yang Dipertua PMM telah menghadiri majlis sambutan sempena kedatangan Sultan Kedah anjuran Kedutaan Tanah Melayu di Kaherah. ${ }^{85}$

Hubungan yang erat juga terjalin antara pelajar Melayu di Kaherah dengan badan pentadbiran dan pemimpin negara, khususnya dari segi penghantaran dokumen bertulis dan majalah rasmi antara kedua-dua pihak. Pada 18 Oktober 1962, Yang Dipertua PMM telah menghantar telegram kepada Dewan Rakyat bagi mengucapkan terima kasih atas kesudian Dewan Rakyat menghantar minit-minit mesyuarat Dewan Rakyat pada sesi yang lepas. Pada tarikh yang sama, Yang Dipertua PMM juga telah menghantar majalah yang diterbitkan oleh PMM kepada Tunku Abdul Rahman berupa tujuh keluaran Warta Persekutuan Melayu Mesir (WPMM) dan dua keluaran majalah terbitan Badan Bahasa dan Pustaka, iaitu salah satu jawatankuasa di bawah PMM. Dalam jawapannya, Tunku Abdul Rahman telah mengucapkan terima kasih atas kesudian PMM menghantar majalah rasmi PMM kepadanya. ${ }^{86}$

Bagi memastikan kebajikan pelajar Melayu di Kaherah mendapat perhatian yang sewajarnya, PMM juga berusaha untuk mewujudkan hubungan yang erat dengan pihak Kedutaan Tanah Melayu di Mesir. Sempena berakhirnya tugas Raja Aznam bin Raja Haji Ahmad sebagai Kuasa Usaha (Duta) Tanah Melayu ke Mesir, Badan Kebajikan PMM telah menganjurkan majlis perpisahan yang dihadiri oleh pelajar-pelajar Melayu di Kaherah pada 26 September 1962. ${ }^{87}$ Beberapa masalah yang timbul juga dapat diselesaikan hasil rundingan antara kedua-dua belah pihak. Pada 8 Jun 1963, wakil PMM telah pergi sendiri ke Kedutaan Tanah Melayu di Kaherah bagi menemui Kuasa Usaha (Duta) Tanah Melayu yang baru iaitu Abdul Manaff Mohammad bagi membincangkan beberapa masalah berkaitan pembinaan Rumah Melayu ${ }^{88}$ Pelajar Melayu juga mempunyai hubungan yang erat dengan Kedutaan British di Kaherah. Pada tahun 1945, seorang pegawai Kedutaan British bernama John Galvin pernah memaklumkan kepada Yang Dipertua PPS, Abdul Jalil Hassan berkenaan Tengku Mahmud Mahyiddin yang akan melawat Mesir. ${ }^{89}$

Semangat kebangsaan dan patriotisme yang tinggi terhadap tanah air juga ditunjukkan oleh pelajar Melayu di Kaherah. Pada 22 Mac 1945, PPS telah mengeluarkan memorandum berkenaan masa hadapan negeri-negeri Melayu selepas pendudukan Jepun. ${ }^{90}$ Pertama, kerajaan Britain dan sekutunya perlu mengakui kebebasan dan kemerdekaan negeri-negeri Melayu, termasuklah diperakui dalam Pertubuhan Bangsa-Bangsa Bersatu (PBB). Kedua, mewujudkan sebuah persekutuan yang mengandungi negeri-negeri Melayu termasuklah Patani (selatan Thailand) kerana penduduk Patani merupakan masyarakat Melayu. 
Ketiga, mengadakan perjanjian antara kerajaan Tanah Melayu dengan kerajaan Britain yang mengakui kebebasan kedua-dua negara, serta menetapkan keperluan tolong-menolong yang melibatkan kemajuan, keamanan dan keselamatan kedua-dua negara. ${ }^{91}$

Beberapa cadangan juga pernah dikemukakan oleh PPS kepada Kongres Agong Melayu berkenaan masa hadapan negeri-negeri Melayu dan orang Melayu hasil daripada mesyuarat tergempar yang telah diadakan pada 5 April 1946. ${ }^{92}$ Pertama, PPS menyokong usul yang dikemukakan oleh Onn Jaafar agar British memberikan kemerdekaan penuh kepada negeri-negeri Melayu selepas pendudukan Jepun. Kedua, PPS mencadangkan agar lebih ramai orang Melayu diberikan latihan secukupnya di tanah air atau dihantar melanjutkan pelajaran di luar negara, seterusnya memegang jawatan dalam kerajaan bagi memajukan bidang ekonomi, perniagaaan dan pertanian dalam masyarakat Melayu. Ketiga, PPS turut mencadangkan agar bahasa Melayu dijadikan bahasa rasmi sebagaimana agama Islam dijadikan agama rasmi di Tanah Melayu. Keempat, PPS juga menuntut agar orang Melayu dapat bekerjasama antara satu sama lain, selain menjauhi sebarang perselisihan, serta mempertahankan kemerdekaan negeri Melayu. ${ }^{93}$

Sempena ulang tahun kemerdekaan Tanah Melayu yang pertama pada tahun 1958, PMM telah mengadakan sambutan Hari Kemerdekaan di pejabat PMM. Antara tetamu kehormat yang hadir ialah Setiausaha Kesatuan Pembebasan Negara-Negara Islam, bekas Panglima Tentera Arab dalam Perang Arab-Palestin, Duta UAR ke Tanah Melayu dan Pegawai Kementerian Luar UAR. ${ }^{94}$ Pada 6 Jun 1962, PMM juga telah bercadang untuk menganjurkan satu majlis sambutan sempena kelahiran Yang di-Pertuan Agong, Tuanku Abdul Rahman yang merupakan Ketua Negara bagi Tanah Melayu. ${ }^{95}$ Pada bulan Ogos 1962, Yang Dipertua PMM bukan sahaja menyeru ahli-ahli PMM agar bersatu-padu, bahkan turut menggalakkan anggota PMM agar terlibat secara langsung dalam penganjuran majlis sambutan sempena Hari kemerdekaan Tanah Melayu kerana:

Nilai dan penghargaan kita terhadap keselamatan tanah air kita dari genggaman penjajah itu akan terbayang dan tergambar di dalam cara-cara dan rupa bentuk penyambutan kita di hari yang bersejarah itu di hadapan bangsa-bangsa yang hadir di perayaan nanti. ${ }^{96}$

Sempena Hari Kemerdekaan Tanah Melayu pada tahun 1962, pengarang WPMM juga telah mengingatkan para pembaca agar memahami maksud kemerdekaan dalam erti kata yang sebenar, khususnya perjuangan golongan nasionalis dan ranjau yang telah 
mereka harungi untuk membebaskan bangsa Melayu daripada cengkaman penjajah kerana:

Lenyapnya penjajahan British di Malaya memberikan peluang yang sebesar-besarnya kepada penduduk Malaya untuk membangun dan membina sebuah negara yang benar-benar bercorak kebangsaan yang tidak mementingkan kaum-kaum yang berusaha memeras dan menindas rakyat jelata, malah seluruh tenaga harus ditujukan untuk kepentingan rakyat. ${ }^{97}$

Bagi memastikan majlis sambutan tersebut berjalan lancar, WPMM juga telah menyeru ahli PMM agar turut sama menyertai sambutan Hari Kemerdekaan tahun 1962 yang akan diadakan di pejabat PMM. Menurut pengarang WPMM lagi:

Kami percaya bahawa tenaga-tenaga yang telah dicurahkan ini kerana persediaan-persediaan sambutan hari ini tidaklah sia-sia, malah selangkah kaki kita bergerak kerana sambutan itu, bererti sebuah batu bata telah kita letakkan untuk memperkuatkan binaan kemegahan negara itu..$^{98}$

Sempena sambutan Hari Kemerdekaan dan Hari Malaysia yang akan diadakan serentak pada 31 Ogos 1963, PMM juga telah menyeru ahlinya agar memberikan sokongan dan seluruh tenaga untuk menjayakan majlis tersebut yang akan diadakan secara besar-besaran sesuai dengan lingkungan negara Malaysia yang semakin besar. ${ }^{99}$ Meskipun rancangan mengadakan sambutan Hari Kemerdekaan dan penubuhan Malaysia secara serentak terpaksa ditunda selepas mendapat maklumat daripada pihak kerajaan tentang penangguhan sambutan tersebut di Malaysia, namun PMM tetap bertekad untuk mengadakan sambutan besar-besaran sempena peristiwa bersejarah tersebut. Pada keluaran 1 Ogos 1963, pengarang WPMM ada menyatakan bahawa:

Sungguhpun perayaan Hari Kemerdekaan itu diundurkan, tetapi kita percaya bahawa setiap warganegara Persekutuan Tanah Melayu (PTM) tentulah memperbaharui iktikad dan cita-cita untuk lebih bergiat membina negara pada masa hadapan, memperbaharui semangat pada tarikh $31 / 8 / 63$ itu. ${ }^{100}$

Pelajar Melayu di Kaherah pernah menyambut ketibaan pemimpin pembangkang dan individu yang mempunyai kaitan dengan golongan kiri. Pada 17 Julai 1962, wakil PMM pernah menyambut kedatangan Yang Dipertua PAS, Dr. Burhanuddin al-Helmy di lapangan terbang Kaherah seterusnya mengadakan beberapa perbincangan dengan beliau. ${ }^{101}$ Pada bulan Ogos 1962, Yang Dipertua PMM juga pernah 
menemui Yang Dipertua Parti Buruh Tanah Melayu, Ishak Haji Muhammad di Hotel Hilton, Kaherah bagi membincangkan beberapa perkara serta bertukar-tukar pandangan. Ishak Haji Muhammad juga telah dijemput untuk menghadiri Majlis Perasmian Bulan Bahasa Kebangsaan, seterusnya dibawa melawat asrama pelajar Melayu di Kaherah serta pejabat PMM. ${ }^{102}$ Pada 27 Oktober 1962, PMM juga pernah menerima kedatangan Kassim Ahmad, bekas Pengerusi Parti Sosialis Rakyat Malaysia (PSRM) ketika dalam perjalanan ke London. Beliau juga telah dibawa melawat pejabat PMM, asrama pelajar Melayu dan Universiti al-Azhar. ${ }^{103}$

Kesedaran politik dalam kalangan pelajar Melayu di Kaherah juga dapat dilihat dari segi pandangan mereka terhadap konsep Melayu Raya atau Malaysia. Pada keluaran 1 September 1962, pengarang WPMM telah mengalu-alukan cadangan penubuhan Melayu Raya yang melibatkan gabungan lima buah wilayah di Alam Melayu sebagaimana yang tersiar dalam akhbar dan majalah di Tanah Melayu.$^{104}$ PMM juga merupakan salah satu contoh terbaik berkenaan konsep Melayu Raya yang akan ditubuhkan kelak kerana ahli PMM terdiri daripada gabungan penduduk Alam Melayu. Menurut pengarang WPMM lagi:

Kita mengharapkan kepada seluruh mahasiswa Melayu di Mesir ini supaya menyedari bahawa besarnya kawasan negara kita dan bertambahnya penduduk negara kita, bererti lebih besar tanggungjawab kita, dan haruslah fikiran kita disesuaikan dengan masa dan keadaan kita. Dirahmati Tuhan hendaknya Melayu Raya. ${ }^{105}$

Pendedahan pelajar Melayu terhadap perkembangan politik di Mesir juga telah membuka minda masyarakat Melayu berkenaan hakikat sebenar perkembangan politik Mesir. Salah seorang pelajar Melayu yang pernah melanjutkan pelajaran dalam bidang Syariah di Kaherah iaitu Osman Ralibi menjelaskan bahawa Mesir sebenarnya mempunyai hubungan yang rapat dengan British dan bersikap pro-British. Menurut beliau lagi, "The people realize that the future of their country lies in the success of Britain's fight against Nazidom, and consequently the people and the press are anti-Nazi and hate Germans". ${ }^{106}$

Pengalaman bergaul dengan pemimpin Mesir serta pendedahan kepada perkembangan politik di Mesir juga telah membentuk jati diri dan kepimpinan pelajar Melayu di Kaherah. Kepimpinan Wan Mokhtar Ahmad, bekas Menteri Besar Terengganu dalam bidang politik misalnya telah diasah ketika belajar di Kaherah. Pengalaman memimpin PMM selama dua sesi berturut-turut iaitu sesi 1960-1961 dan 1961-1962 juga mendedahkan beliau kepada perkembangan politik Mesir dan Tanah Melayu. Semasa menjadi Yang Dipertua PMM, Wan Mokhtar pernah 
menulis surat kepada bekas Timbalan Perdana Menteri, Abdul Razak bagi memohon bantuan kewangan yang akan digunakan bagi menyewa sebuah bangunan sebagai ibu pejabat PMM, serta perbelanjaan untuk menguruskan kegiatan PMM. Beliau juga pernah menulis surat kepada Presiden Mesir, Gamal Abdel Nasser untuk memohon tanah bagi pembinaan ibu pejabat PMM, bahkan telah menemui presiden untuk mengetahui perkembangannya. ${ }^{107}$ Meskipun telah melepaskan jawatan sebagai Yang Dipertua PMM, beliau masih bersemangat untuk berbakti kepada PMM. Ketika Abdul Kadir Talib bertugas selaku Yang Dipertua PMM pada sesi 1962-1963, beliau dipilih sebagai Ahli Jawatankuasa Rumah Melayu. ${ }^{108}$

Walau bagaimanapun, penglibatan pelajar Melayu di Kaherah dalam bidang politik turut membimbangkan segelintir orang Melayu. Pada tahun 1952, seorang sarjana Melayu iaitu Za'ba (Zainal Abidin bin Ahmad) ketika menyampaikan ucapan dalam Perhimpunan Agong Persekutuan Pelajar Melayu Tanah Melayu (PPMTM) Ke-5 di Victoria Institution, Kuala Lumpur menjelaskan bahawa pelajar Melayu tidak patut terlibat dalam politik, malah tidak patut mengikut tindakan pelajar Melayu di Kaherah yang melibatkan diri dalam politik. ${ }^{109} \mathrm{Hal}$ ini menunjukkan bahawa segelintir pihak berpendapat bahawa pelajar Melayu di Kaherah sepatutnya memberikan sepenuh perhatian kepada pelajaran dan tidak melibatkan diri dalam kegiatan bercorak politik yang dikhuatiri akan mengganggu pelajaran dan menjejaskan tumpuan mereka terhadap pelajaran.

\section{Kesimpulan}

Pelajar Melayu terlibat secara aktif dalam pelbagai kegiatan bercorak politik dan sosial sejak Perang Dunia Pertama lagi. Peristiwa Perang Dunia Kedua pula dilihat langsung tidak mempengaruhi semangat pelajar Melayu untuk belajar di Mesir, malah jumlah pelajar Melayu yang menyambung pelajaran di Kaherah semakin bertambah selepas Perang Dunia Kedua. Bagi memastikan kebajikan mereka terbela, pelajar Melayu juga telah mengambil inisiatif untuk mewujudkan hubungan yang baik dengan kerajaan Mesir, termasuklah Presiden Mesir, Gamal Abdel Nasser selain dengan pengurusan tertinggi Universiti al-Azhar dan Majlis Agama Islam di Mesir. Bagi mengeratkan hubungan silaturahim sesama pelajar, pelajar Melayu di Kaherah juga menjalinkan hubungan dengan pertubuhan pelajar di Mesir, selain pertubuhan pelajar yang mewakili negara Timur Tengah, Afrika dan Asia Tenggara. Hubungan erat juga dijalinkan dengan pertubuhan pelajar Melayu di Makkah.

Walaupun aktif menjalinkan hubungan negara luar, pelajar Melayu di Kaherah tetap menjaga hubungan dengan pemimpin Tanah Melayu, 
khususnya dengan menteri kabinet dan pegawai kerajaan. Malah pelajar Melayu di Kaherah juga pernah bertukar-tukar dokumen dan majalah rasmi dengan kerajaan Tanah Melayu. Pelajar Melayu di Kaherah bukan sahaja mempunyai hubungan yang baik dengan negeri-negeri Melayu dan raja-raja Melayu, malah berusaha untuk mewujudkan hubungan yang erat dengan pihak Kedutaan Tanah Melayu di Mesir bagi memastikan kebajikan pelajar Melayu di Kaherah mendapat perhatian yang sewajarnya. Semangat kebangsaan dan patriotisme yang tinggi terhadap tanah air juga ditunjukkan oleh pelajar Melayu di Kaherah. PMM bukan sahaja mengadakan sambutan Hari Kemerdekaan sempena ulang tahun kemerdekaan Tanah Melayu yang pertama, malah pernah mengemukakan cadangan kepada Kongres Agong Melayu berkenaan masa hadapan negeri-negeri Melayu dan orang Melayu. Pelajar Melayu di Kaherah juga tidak mengutamakan ideologi politik dalam kegiatan persatuan. Meskipun mempunyai hubungan yang baik dengan kerajaan, pelajar Melayu di Kaherah turut menyambut ketibaan pemimpin pembangkang dan individu yang mempunyai kaitan dengan golongan kiri yang melawat Kaherah. Bahkan pelajar Melayu di Kaherah juga menyokong konsep Melayu Raya yang dipercayai dapat menyatukan ahli-ahli PMM yang datang dari seluruh Asia Tenggara, termasuklah Tanah Melayu dan Indonesia. Walaupun pelajar Melayu di Kaherah tidak terlibat secara langsung dalam perjuangan menuntut kemerdekaan Tanah Melayu, namun mereka turut memainkan peranan penting dalam menyemai kesedaran terhadap kepentingan membebaskan negara daripada belenggu penjajah dan berkerajaan sendiri selepas pulang ke tanah air.

\section{Nota}

Neracha, Jil. 4, Bil. 124, 25 Februari 1914, hlm. 3.

$2 \quad$ Ni'mah Haji Ismail, "The Life and Thoughts of Shaykh Muhammad Fadlullah Suhaimi", Tesis M.Litt., University of Edinburgh, 1994, hlm. 38. Sudah menjadi kelaziman bagi penerbit atau pengarang ketika itu untuk mencetak akhbar atau majalah mereka sendiri bagi mengurangkan kos editorial dan penerbitan yang melibatkan kos yang tinggi jika dicetak dengan syarikat percetakan luar. Lihat Hamedi Mohd. Adnan, "Majalah-Majalah Agama Sebelum Perang dan Ekonomi Penerbitannya", dalam Hashim Awang A. R. et al. (ed.), Pengajian Sastera dan Sosiobudaya Melayu Memasuki Alaf Baru, Kuala Lumpur: Akademi Pengajian Melayu, Universiti Malaya, 1998, hlm. 150.

3 Lihat "Kanun (Peraturan) Syarikat al-Ittihad di Mesir", Neracha, Jil. 4, Bil. 124, 25 Februari 1914, hlm. 3.

4 Muhammad Fadlullah Suhaimi, Kitab Pelajaran Tauhid, Kaherah: Matbaah al-Ittihadiyyah, 1914. 
Md. Sidin Ahmad Ishak, Penerbitan dan Percetakan Buku Melayu, 1807-1960, Kuala Lumpur: Dewan Bahasa dan Pustaka, 1998, hlm. 163.

$6 \quad$ Abdullah al-Qari Haji Salleh, Sejarah Hidup To' Kenali, Kota Bharu, Pustaka Aman Press, 1967, hlm. 113.

$7 \quad$ Seruan Azhar, Jil. 3, Bil. 30, Mac 1928, hlm. 585; Seruan Azhar, Jil. 3, Bil. 31, April 1928, hlm. 605.

8 Shaykh Junid Tola al-Azhari, Kitab Kaifiyat Mengadakan Wakaf, Kaherah: Matbaah al-Marbawiyyah, 1930. Untuk maklumat lanjut tentang Shaykh Junid Tola, lihat Siti Hanifah Ahmad, "Syeikh Junid Tola: Sumbangannya Dalam Bidang Pendidikan dan Politik, 1889-1948”, Latihan Ilmiah B.A., 1988, Universiti Malaya.

$9 \quad$ Md. Sidin Ahmad Ishak, Penerbitan dan Percetakan Buku Melayu, hlm. 84. Menurut Md. Sidin, kitab tersebut berjudul Ini Huraian Yang Membakar: Taman Persuratan Haji Bakar Pada Menyatakan Hukum Dua Rakaat Kiblat [Qabla] al-Jum'at.

Selain dicetak oleh Matbaah al-Marbawiyyah, Kamus al-Marbawi juga pernah dicetak oleh Matbaah Mustafa al-Babi al-Halabi. Lihat Muhammad Idris al-Marbawi, Kamus al-Marbawi, Kaherah: Matbaah Mustafa al-Babi al-Halabi, 1930.

Seruan Azhar, Jil. 1, Bil. 3, Disember 1925, hlm. belakang; Seruan Azhar, Jil. 1, Bil. 4, Januari 1926, hlm. 77. Kamus al-Marbawi bukanlah kamus Melayu-Arab pertama yang dihasilkan oleh penulis Melayu. Sebuah kamus berjudul Kamus Mahmudiyyah telah ditulis oleh Sayyid Mahmud bin Sayyid Abdul Kadir diterbitkan buat pertama kalinya pada tahun 1894. Kamus ini pernah diterbitkan semula di Kota Bharu, Kelantan pada tahun 1924. Selain itu, Kamus Mahmudiyyah juga pernah dicetak oleh Syarikat Percetakan D. Y. Brothers di Kota Bharu, Kelantan dan dijual dengan harga \$1.30 termasuklah belanja pos. Wakil penjual Kamus Mahmudiyyah juga terdapat di Pulau Pinang iaitu Haji Abdul Halim dan di Yan, Kedah iaitu Haji Muhammad Said. Lihat Pengasoh, Jil. 7. Bil. 169, 24 April 1925, hlm. 12; Pengasoh, Jil. 8. Bil. 171, 23 Mei 1925, hlm. 12; Pengasoh, Jil. 8, Bil. 184, 30 November 1925, hlm. 12.

12 Pilehan Timoer, Jil. 1, Bil. 1, Oktober 1927, hlm. 16. Selain menerbitkan syarikat percetakan sendiri, pelajar Melayu di Mesir juga pernah memohon kitab dan buku daripada majlis agama di negeri-negeri Melayu. Pelajar Melayu di Mesir melalui Persekutuan Putera-Putera Semenanjung (PPS) misalnya pernah memohon hadiah berupa kitab dan buku dalam bahasa Melayu daripada Majlis Agama Islam dan Adat Istiadat Melayu Kelantan (MAIK). Lihat Setiausaha PPS kepada Setiausaha MAIK, 6 Oktober 1933, dalam MAIK 170/1933, Memohonkan Hadiah Buku-Buku Ilmu dan Cerita-Cerita Bahasa Melayu Karangan Pembesar-Pembesar Kelantan Kepada Persekutuan Itu Bagi Bacaan Anak-Anak Melayu di Mesir.

$13 \quad$ Pilehan Timoer, Jil. 1, Bil. 1, Oktober 1927, hlm. 1.

$14 \quad$ Md. Sidin Ahmad Ishak, Penerbitan dan Percetakan Buku Melayu, hlm. 77.

15 Wawancara dengan Razali bin Nawawi di Bandar Baru Bangi, Selangor, 4 Januari 2013. 
16 Wawancara dengan Wan Mokhtar bin Ahmad di Shah Alam, Selangor, 16 Januari 2013.

17 Wawancara dengan Muhammad Dahlan bin Arshad di Bangi Perdana, Selangor, 24 April 2012.

18 Lihat William R. Roff, "The Life and Times of Haji Othman Abdullah", Peninjau Sejarah, Vol. 1, No. 2, 1966, hlm. 63.

19 Mona Abaza, Changing Images of Three Generations of Azharites in Indonesia, Singapore: ISEAS, Occasional Paper No. 88, 1993, p. 7.

$20 \quad$ Haji Omar Said Tjokroaminoto (1883-1934) merupakan seorang pemimpin Sarekat Islam di Indonesia. Untuk keterangan lanjut mengenai beliau, lihat Theodore Friend, Indonesian Destinies, Harvard: Harvard University Press, 2003, hlm. 25. Haji Mansur (1896-1946) pula merupakan seorang pemimpin Sarekat Islam dan Muhammadiyah di Indonesia. Untuk keterangan lanjut tentang beliau, lihat Darul Aqsha, K. H. Mas Mansur (1896-1946): Perjuangan dan Pemikiran, Jakarta: Penerbit Erlangga, 2005, hlm. 80-85.

Pengarang al-Manar juga melaporkan bahawa antara usul lain yang dibahaskan dalam perhimpunan tersebut ialah penentangan terhadap pemerintah Semenanjung Tanah Arab iaitu Ibn Saud. Selain itu, terdapat juga umat Islam yang menyeru agar orang Melayu meninggalkan ibadah haji selagi Ibn Saud masih berkuasa, bahkan mereka turut menyeru umat Islam lain agar tidak menunaikan solat dengan menghala ke arah kiblat yang terletak di Masjid al-Haram, Makkah. Lihat al-Manar, Jil. 28, Bil. 8, 5 November 1926, hlm. 638-639.

Al-Jamiyyah al-Khairiyyah al-Talabiyyah al-Azhariyyah al-Jawah atau Persatuan Kebajikan Pelajar-Pelajar Jawi al-Azhar (selepas ini disebut al-Jamiyyah al-Khairiyyah sahaja) ditubuhkan pada tahun 1923 bagi menjaga kebajikan pelajar Melayu di Mesir. Lihat Seruan Azhar, Jil. 1, Bil. 2, November 1925, hlm. 35.

Muktamar Alam Islami atau Persidangan Umum Islam telah dianjurkan oleh Mufti Jurusalem (Palestin) bertujuan untuk menyatukan pandangan umat Islam bagi mempertahankan bumi Palestin. Lihat Mohammad Redzuan Othman, "The Middle East Influence on the Development of Religious and Political Thought in Malay Society, 1880-1940", Tesis Ph.D., University of Edinburgh, 1994, hlm. 278.

24 Ibid., hlm. 279.

25 Seruan Azhar, Jil. 2, Bil. 17, Februari 1927, hlm. 325-326.

26 Pengasoh, Jil. 7, Bil. 159, 27 November 1924, hlm. 3. Shaykh Abdul Aziz Jawish (1872-1929) dilahirkan di Iskandariyah, Mesir dan pernah mendapat pendidikan di Universiti al-Azhar, Dar al-Ulum dan London's Borough Road Teacher's Training College. Beliau pernah mengajar bahasa Arab di Universiy of Cambridge. Sekembalinya ke Mesir, beliau pernah menjadi Inspektor Bahasa Arab untuk Kementerian Pelajaran Mesir, namun meletak jawatan pada tahun 1908 untuk berkhidmat sebagai editor akhbar al-Liwa, iaitu majalah rasmi Parti Nasionalis. Beliau juga pernah menjadi editor majalah al-Hilal dan al-Hidayah, malah beliau juga pernah bekerja dengan Kemal Ataturk, namun bertindak meletak jawatan setelah Kemal memansuhkan sistem khalifah pada tahun 1923. Beliau kembali ke Mesir 
pada tahun 1923 dan bekerja semula dengan Kementerian Pelajaran dan pernah dilantik sebagai Timbalan Presiden Jamiyyah al-Shubban alMuslimin (Persatuan Belia Islam) sebelum beliau meninggal dunia. Lihat Arthur Goldschmidt Jr., Biographical Dictionary of Modern Egypt, Colorado: Lynne Rienner Publishers Inc., 2000, hlm. 96-97.

Haji Wan Musa (1874-1939) merupakan bekas Mufti Kelantan (19081916). Beliau juga terdedah secara langsung terhadap perkembangan pemikiran islah di Mesir yang perjuangkan oleh Muhammad Rashid Rida, malah pernah mengutus surat kepada beliau. Lihat Nik Abdul Aziz Haji Nik Hassan, "Sejarah Gerakan dan Perkembangan Alam Pemikiran Islam di Jajahan Kota Bharu, 1900-1940-an", Latihan Ilmiah B.A., Universiti Kebangsaan Malaysia, 1973, hlm. 32-38. Winzeler yang mengkaji kehidupan masyarakat Kelantan dalam tesis kedoktorannya mungkin tersilap kerana menamakan bekas Mufti Kelantan tersebut yang meninggal dunia pada tahun 1939 sebagai Haji Wan Isahak. Lihat Robert Winzeler, "Malay Religion, Society and Politics in Kelantan", Disertasi Ph.D., University of Chicago, 1970, hlm. 150.

Muhammad Salleh Wan Musa \& S. Othman Kelantan, "Theological Debates: Wan Musa b. Haji Abdul Samad and His Family", dalam William R. Roff (ed.), Kelantan: Religion, Society and Politics in a Malay States, Kuala Lumpur: Oxford University Press, 1974, hlm. 161. Mu $\square$ tafa Kamil (18741908) merupakan pejuang kemerdekaan Mesir dan mempunyai hubungan yang erat dengan kerajaan Turki Uthmaniyah sehingga dianugerahkan gelaran "Pasha" pada tahun 1904. Beliau juga merupakan pengasas Hizb al-Watani (Parti Nasionalis) pada tahun 1907 dan meninggal dunia ketika berusia 34 tahun. Lihat James Jankowski, "Ottomanism and Arabism in Egypt, 1860-1914", The Muslim World, Vol. 70, 1980, hlm. 235-236. Masyarakat Melayu juga menghormati Mu $\square$ tafa Kamil sebagai seorang pejuang kebangsaan Mesir. Ucapan beliau pernah disiarkan dalam majalah Chahaya Pulau Pinang selama tiga keluaran berturut-turut pada tahun 1900. Majalah al-Imam bukan sahaja menyiarkan berita kematian Mustafa Kamil pada tahun 1908, malah berjanji untuk menyiarkan sejarah hidup dan perjuangan politik beliau. Lihat Mohammad Redzuan Othman, "Peranan Pengaruh Mesir Dalam Perkembangan Kesedaran Politik Masyarakat Melayu Sebelum Perang Dunia II", dalam Hashim Awang A. R. et al. (ed.), Pengajian Sastera dan Sosiobudaya Melayu Memasuki Alaf Baru, Kuala Lumpur: Akademi Pengajian Melayu, UM, 1998, hlm. 327. Ismail Awang, "Mufti Haji Wan Musa", dalam Ismail Che Daud (ed.), Tokoh-Tokoh Ulama' Semenanjung Melayu, Jilid I, Kota Bharu: Majlis Ugama Islam dan Adat Istiadat Melayu Kelantan, 1988, hlm. 213. Shaykh Tantawi al-Jawhari (1862-1940) dilahirkan di Zaqaziq, Mesir dan pernah belajar di Universiti al-Azhar dan Dar al-Ulum, Kaherah. Setelah menamatkan pengajian di Dar al-Ulum pada tahun 1893, beliau kemudian bertugas sebagai pendidik dan pernah mengajar di Dar al-Ulum dan Universiti Kaherah sebelum bersara pada tahun 1922. Beliau juga aktif menyumbangkan tulisan dalam majalah al-Liwa' iaitu suara rasmi Hizb al-Watani. Karya beliau yang terkenal ialah sebuah kitab tafsir berjudul 
al-Jawahir fi Tafsir al-Quran al-Karim yang mempunyai 26 jilid. Untuk keterangan lanjut, lihat Arthur Goldschmidt Jr., Biographical Dictionary of Modern Egypt, hlm. 96.

Lihat "Federal Flag", The Straits Times, 31 March 1949, hlm. 5.

31 Shaykh Abdul Rahim al-Samnudi kepada Tengku Besar Pahang, 1 April 1948, dalam JAIP 60/1948, Hendak Diadakan Keramaian di Kuliah Kerana Menyampaikan Gambar al-Malik Farouk dan Membuka Kitab Khanah Kepada Kuliah al-Lughah wa al-Din di Pekan. Lihat "Talk on Egypt by Professor", The Straits Times, 28 October 1965, hlm. 5 .

33 Pada peringkat awal, ceramah tersebut telah dirancang untuk diadakan pada 5 November 1965. Namun begitu, beberapa masalah yang timbul menyebabkan ceramah tersebut telah ditunda kepada 12 November 1965. Lihat "Talk on Egypt by Professor", The Straits Times, 10 November 1965, hlm. 4 . SP 142/9, Warta Persekutuan Melayu Mesir, Jil. 1, Bil. 2, 1 Mac 1962, hlm. 4. Salah Salim adalah bekas Menteri Perpaduan Negara UAR (Mesir) dalam kabinet Presiden Nasser, dan merupakan antara Free Officers yang terlibat dalam gerakan menjatuhkan Raja Mesir, Raja Faruq yang dipimpin oleh Gamal Abdel Nasser pada tahun 1952. Lihat Elie Podeh, The Quest for Hegemony in the Arab World: The Struggle over the Baghdad Pact, Leiden: Brill, 1995, hlm. 25.

SP 142/9, Warta Persekutuan Melayu Mesir, Jil. 1, Bil. 7, 1 Ogos 1962, hlm. 1. Presiden Nasser kemudian telah membalas telegram Yang Dipertua PMM, Abdul Kadir Talib pada 2 Jun 1962 dan telah mengucapkan terima kasih atas ingatan PMM dan pelajar Melayu di Mesir terhadap beliau. Lihat SP 142/9, Warta Persekutuan Melayu Mesir, Jil. 1, Bil. 7, 1 Ogos 1962, hlm. 2. SP 142/9, Warta Persekutuan Melayu Mesir, Jil. 1, Bil. 16, 15 Disember 1962, hlm. 2. SP 142/9, Warta Persekutuan Melayu Mesir, Jil. 2, Bil. 21, 15 Jun 1963, hlm. 5. SP 142/9, Warta Persekutuan Melayu Mesir, Jil. 2, Bil. 19, 1 Mac 1963, hlm. 1. SP 142/9, Warta Persekutuan Melayu Mesir, Jil. 2, Bil. 21, 15 Jun 1963, hlm. 4.

40 SP 142/9, Warta Persekutuan Melayu Mesir, Jil. 1, Bil. 7, 1 Ogos 1962, hlm. 1. Presiden Nasser kemudian telah membalas telegram Yang Dipertua PMM, Abdul Kadir Talib pada 2 Jun 1962 dan mengucapkan terima kasih atas ingatan PMM dan pelajar Melayu di Mesir terhadap beliau. Lihat SP 142/9, Warta Persekutuan Melayu Mesir, Jil. 1, Bil. 7, 1 Ogos 1962, hlm. 2. Shaykh Mahmud Shaltut (1893-1963) merupakan Rektor Universiti al-Azhar ketika pemerintahan Presiden Nasser. Beliau menamatkan pengajian di Universiti al-Azhar pada tahun 1918. Beliau pernah bekerja sebagai peguam (1931-1935) sebelum dilantik sebagai Dekan Fakulti Syariah, Universiti alAzhar. Beliau kemudian dilantik sebagai Rektor Universiti al-Azhar pada 
tahun 1958, dan berkhidmat sehingga kematiannya pada tahun 1963. Lihat Arthur Goldschmidt Jr., Biographical Dictionary of Modern Egypt, hlm. 188. SP 142/9, Warta Persekutuan Melayu Mesir, Jil. 1, Bil. 12, 15 Oktober 1962, hlm. 2.

42 SP 142/9, Warta Persekutuan Melayu Mesir, Jil. 2, Bil. 19, 1 Mac 1963, hlm. 1.

43 SP 142/9, Warta Persekutuan Melayu Mesir, Jil. 2, Bil. 21, 15 Jun 1963, hlm. 4.

44 SP 142/9, Warta Persekutuan Melayu Mesir, Jil. 1, Bil. 12, 15 Oktober 1962, hlm. 2.

45 SP 142/9, Warta Persekutuan Melayu Mesir, Jil. 2, Bil. 19, 1 Mac 1963, hlm. 4.

46 SP 142/9, Warta Persekutuan Melayu Mesir, Jil. 2, Bil. 22, 1 Julai 1963, hlm. 4. Haji Yusuf Rawa merupakan bekas Presiden PAS (1982-1989) yang menggantikan Asri Muda (1971-1982). Haji Yusuf Rawa kemudian digantikan oleh Haji Fadzil Noor (1989-2002) selaku Presiden PAS. Lihat Liew Chin Tong, "PAS Politics: Defining an Islamic State", dalam Edmund Terence Gomez (ed.), Politics in Malaysia: The Malay Dimension, Oxon: Routledge, 2007, hlm. 111. SP 142/9, Warta Persekutuan Melayu Mesir, Jil. 1, Bil. 4, 1 April 1962, hlm. 5. Qalyub merupakan sebuah daerah yang terletak di utara Kaherah. SP 142/9, Warta Persekutuan Melayu Mesir, Jil. 1, Bil. 6, 1 Mei 1962, hlm. 1. Bantuan dalam jumlah yang sama juga telah diberikan kepada PMM pada bulan Jun 1962. Lihat SP 142/9, Warta Persekutuan Melayu Mesir, Jil. 1, Bil. 7, 1 Ogos 1962, hlm. 2. Ibid., hlm. 3. Asyut merupakan sebuah daerah yang terletak di wilayah tengah Mesir, iaitu di selatan Kaherah. SP 142/9, Warta Persekutuan Melayu Mesir, Jil. 1, Bil. 7, 1 Ogos 1962, hlm. 3.

51 Mereka yang telah dilantik ialah Ishak Muhammad Rejab, Yahya Othman dan Muhammad Ali Harun. Lihat SP 142/9, Warta Persekutuan Melayu Mesir, Jil. 1, Bil. 13, 1 November 1962, hlm. 1.

52 Majlis Berbuka Puasa anjuran Persatuan Pelajar-Pelajar UAR turut dihadiri oleh wakil persatuan pelajar Asia dan Afrika serta Menteri Belia UAR, manakala Majlis Berbuka Puasa anjuran Nadi al-Wafidin pula dihadiri oleh wakil persatuan pelajar Asia dan Afrika serta pegawai Kementerian Pengajian Tinggi UAR. Lihat SP 142/9, Warta Persekutuan Melayu Mesir, Jil. 2, Bil. 19, 1 Mac 1963, hlm. 1. SP 142/9, Warta Persekutuan Melayu Mesir, Jil. 1, Bil. 7, 1 Ogos 1962, hlm. 3. SP 142/9, Warta Persekutuan Melayu Mesir, Jil. 1, Bil. 12, 15 Oktober 1962, hlm. 2. SP 142/9, Warta Persekutuan Melayu Mesir, Jil. 1, Bil. 15, 1 Disember 1962, hlm. 3-4.

56 Ibid., hlm. 4.

57 Menurut Wan Mokhtar Ahmad, beliau merupakan Yang Dipertua PMM pertama yang mengadakan kerjasama antara pelajar Asia Tenggara di 
Mesir. Lihat Sharif Putera, Sekali Angin Menderu: Biografi Dato' Seri Amar Di Raja, Tan SriWan Mokhtar bin Ahmad, Kuala Terengganu: PELITA, 1999, hlm. 56. SP 142/9, Warta Persekutuan Melayu Mesir, Jil. 1, Bil. 2, 1 Mac 1962, hlm. 4.

Lee Kuan Yew juga telah menyampaikan ceramah berkaitan perkembangan politik di Singapura dan Tanah Melayu. Lihat SP 142/9, Warta Persekutuan Melayu Mesir, Jil. 1, Bil. 5, 15 April 1962, hlm. 3.

SP 142/9, Warta Persekutuan Melayu Mesir, Jil. 1, Bil. 8, 15 Ogos 1962, hlm. 3.

SP 142/9, Warta Persekutuan Melayu Mesir, Jil. 1, Bil. 9, 1 September 1962, hlm. 2.

SP 142/9, Warta Persekutuan Melayu Mesir, Jil. 1, Bil. 15, 1 Disember 1962, hlm. 3.

SP 142/9, Warta Persekutuan Melayu Mesir, Jil. 1, Bil. 16, 15 Disember 1962, hlm. 3.

SP 142/9, Warta Persekutuan Melayu Mesir, Jil. 2, Bil. 19, 1 Mac 1963, hlm. 1.

SP 142/9, Warta Persekutuan Melayu Mesir, Jil. 2, Bil. 22, 1 Julai 1963, hlm. 5. Dokki merupakan sebuah daerah yang terletak berhampiran Giza dan bersebelahan dengan Kaherah.

Memorandum Penuntut-Penuntut Melayu di Mesir Berkenaan Dengan Negeri-Negeri Melayu di Masa Akan Datang, dalam SP 92, Fail Berkenaan UMNO, 1945-1950. Tengku Mahmud Mahyiddin ketika itu merupakan seorang pegawai yang berkhidmat dalam Malay Administrative Services (MAS) di Kelantan. Beliau merupakan bapa saudara kepada bekas Menteri Luar, Tengku Ahmad Rithauddeen dan merupakan anak kepada Raja Patani terakhir. Lihat Alias Mohamed, Kelantan di Bawah Kepimpinan PAS: Masalah Tanah dan Rasuah, Kuala Lumpur: Insular Publishing House, 1984, hlm. 51.

Setiausaha Mesyuarat Menteri Besar Negeri-Negeri Melayu kepada Menteri Besar Terengganu, 5 Mei 1949, dalam SUK Tr. 617/1948, Malay Association in Egypt.

Abdul Aziz tiba di Kaherah bagi mewakili kerajaan Tanah Melayu dalam Persidangan Kemajuan Luar Bandar Asia-Afrika. Lihat SP 142/9, Warta Persekutuan Melayu Mesir, Jil. 1, Bil. 4, 1 April 1962, hlm. 4.

SP 142/9, Warta Persekutuan Melayu Mesir, Jil. 1, Bil. 4, 1 April 1962, hlm. 5 .

Dalam majlis sambutan tersebut, Syed Nasir Ismail juga telah mengambil kesempatan untuk menyampaikan ceramah berkenaan perkembangan bahasa Melayu di tanah air. Lihat SP 142/9, Warta Persekutuan Melayu Mesir, Jil. 1, Bil. 5, 15 April 1962, hlm. 2. Syed Nasir Ismail juga merupakan bekas Speaker Dewan Rakyat (p. 1978-1982).

SP 142/9, Warta Persekutuan Melayu Mesir, Jil. 1, Bil. 7, 1 Ogos 1962, hlm. 1. Sardon Jubir (1917-1985) dilahirkan di Rengit, Johor dan merupakan Naib Presiden UMNO. Beliau pernah dilantik sebagai menteri kabinet iaitu sebagai Menteri Pengangkutan, Menteri Kesihatan serta Menteri 
Kerja Raya dan Perhubungan sebelum dilantik sebagai Yang di-Pertua Negeri Pulau Pinang. Lihat "Sardon Jubir Meninggal Dunia", Berita Harian, 16 Disember 1985, hlm. 1. Untuk maklumat lanjut tentang Sardon Jubir, lihat Cecilia Tan, Tun Sardon Jubir: His Life \& Times, Subang Jaya: Pelanduk Publications, 1986. SP 142/9, Warta Persekutuan Melayu Mesir, Jil. 1, Bil. 7, 1 Ogos 1962, hlm. 2-3.

SP 142/9, Warta Persekutuan Melayu Mesir, Jil. 1, Bil. 15, 1 Disember 1962, hlm. 4. Sebelum itu, Kapten Abdul Hamid Khan bin Haji Shakawat pernah memegang jawatan Timbalan Menteri Pelajaran. Beliau telah dilantik sebagai Menteri Pelajaran menggantikan Abdul Rahman Talib berkuatkuasa pada 10 Oktober 1962. Lihat "Cabinet Jobs Switch Today", The Straits Times, 10 October 1962, hlm. 10.

Timbalan Menteri Perdagangan dan Industri ketika itu merupakan Haji Abdul Khalid bin Awang Osman. Lihat "Cabinet Reshuffle", The Straits Times, 2 October 1962, hlm. 1.

SP 142/9, Warta Persekutuan Melayu Mesir, Jil. 2, Bil. 19, 1 Mac 1963, hlm. 4.

Kepulangan Othman Abdullah pada 3 Mac 1963 juga telah diraikan oleh wakil PMM di Lapangan Terbang Kaherah. Lihat SP 142/9, Warta Persekutuan Melayu Mesir, Jil. 2, Bil. 21, 15 Jun 1963, hlm. 5.

SP 142/9, Warta Persekutuan Melayu Mesir, Jil. 2, Bil. 21, 15 Jun 1963, hlm. 5.

SP 142/9, Warta Persekutuan Melayu Mesir, Jil. 2, Bil. 23, 15 Julai 1963, hlm. 1-2. Pertemuan tersebut telah diatur oleh Kedutaan Tanah Melayu di Mesir setelah PMM mengambil keputusan untuk tidak menyokong perasmian Rumah Melayu kerana berpendapat bahawa pembinaan Rumah Melayu belum siap sepenuhnya khususnya dari segi ketiadaan peralatan dan perabot yang lengkap.

SP 142/9, Warta Persekutuan Melayu Mesir, Jil. 1, Bil. 16, 15 Disember 1962, hlm. 2.

SP 142/9, Warta Persekutuan Melayu Mesir, Jil. 2, Bil. 19, 1 Mac 1963, hlm. 4.

The Singapore Free Press, 10 August 1950, hlm. 5.

SP 142/9, Warta Persekutuan Melayu Mesir, Jil. 1, Bil. 7, 1 Ogos 1962, hlm. 2.

SP 142/9, Warta Persekutuan Melayu Mesir, Jil. 2, Bil. 21, 15 Jun 1963, hlm. 5.

Ibid., hlm. 3.

SP 142/9, Warta Persekutuan Melayu Mesir, Jil. 2, Bil. 22, 1 Julai 1963, hlm. 5 .

SP 142/9, Warta Persekutuan Melayu Mesir, Jil. 1, Bil. 15, 1 Disember 1962, hlm. 3.

SP 142/9, Warta Persekutuan Melayu Mesir, Jil. 1, Bil. 11, 1 Oktober 1962, hlm. 1. Selepas menamatkan perkhidmatan sebagai Duta Tanah Melayu ke Mesir, Raja Aznam juga pernah dilantik sebagai Duta Malaysia ke Bangkok, India, Nepal dan Jepun. Beliau juga pernah dilantik sebagai 
Ketua Setiausaha Kementerian Luar Negeri dan Timbalan Wakil Tetap Malaysia ke Pertubuhan Bangsa-Bangsa Bersatu (PBB). Lihat "New Malaysian Envoy", The Straits Times, 12 August 1971, hlm. 2. Lihat juga "He's Off to Take up Job at U.N.", The Straits Times, 31 July 1965, hlm. 6. SP 142/9, Warta Persekutuan Melayu Mesir, Jil. 2, Bil. 21, 15 Jun 1963, hlm. 3.

Galvin kepada Abdul Jalil, 15 November 1943, dalam SP 92, Fail Berkenaan UMNO, 1945-1950.

Memorandum tersebut telah digubal oleh PPS atas permintaan Tengku Mahmud Muhyiddin yang telah singgah di Kaherah pada 7 Februari 1945. Beliau meminta PPS memberikan pandangan berkenaan masa hadapan negeri-negeri Melayu sebagaimana memorandum yang digubal oleh pelajar Melayu di England.

Memorandum Penuntut-Penuntut Melayu di Mesir Berkenaan Dengan Negeri-Negeri Melayu di Masa Akan Datang, dalam SP 92, Fail Berkenaan UMNO, 1945-1950.

2 Kongres Agong Melayu telah diadakan di Kelab Sulaiman, Kuala Lumpur pada 1 Mac 1946 dan dipimpin oleh Onn Jaafar selaku pengerusi kongres. Penganjuran kongres tersebut yang dihadiri oleh raja-raja Melayu iaitu Sultan Selangor dan Sultan Kedah serta lebih 40 buah persatuan negeri Melayu bukan sahaja membawa kepada penubuhan UMNO, tetapi juga menzahirkan bantahan terhadap Malayan Union. Lihat Ramlah Adam, Kemelut Politik Semenanjung Tanah Melayu, Kuala Lumpur: Penerbit UM, 2004, hlm. 6-7.

Kenyataan dan Cadangan Persekutuan Putera-Putera Semenanjung di Mesir Kepada Majlis Perjumpaan Melayu Agong, 5 April 1935, dalam SP 92, Fail Berkenaan UMNO, 1945-1950.

SP 65/3, Pengasoh, Bil. 311, Oktober 1958, hlm. 2.

SP 142/9, Warta Persekutuan Melayu Mesir, Jil. 1, Bil. 7, 1 Ogos 1962, hlm. 2.

SP 142/9, Warta Persekutuan Melayu Mesir, Jil. 1, Bil. 8, 15 Ogos 1962, hlm. 3.

SP 142/9, Warta Persekutuan Melayu Mesir, Jil. 1, Bil. 9, 1 September 1962, hlm. 1 .

Ibid.

SP 142/9, Warta Persekutuan Melayu Mesir, Jil. 2, Bil. 21, 15 Jun 1963, hlm. 6.

SP 142/9, Warta Persekutuan Melayu Mesir, Jil. 2, Bil. 26, 1 September 1963, hlm. 1. Penangguhan sambutan Hari Kemerdekaan pada tahun tersebut tercetus selepas Perdana Menteri Singapura, Lee Kuan Yew mahu menjadikan tarikh 31 Ogos yang merupakan Hari Kemerdekaan Tanah Melayu sebagai tarikh sambutan Hari Malaysia sempena penubuhan Malaysia. Lihat Mohamad Abu Bakar, "Seeds of Separation", dalam Takashi Shiraishi (ed.), Across the Causeway: A Multi Dimensional Study of Malaysia-Singapore Relations, Singapore: Institute of Southeast Asian Studies (ISEAS), 2009, hlm. 71. 
101 SP 142/9, Warta Persekutuan Melayu Mesir, Jil. 1, Bil. 7, 1 Ogos 1962, hlm. 3. Dr. Burhanuddin al-Helmy (1911-1969) dilahirkan di Gopeng, Perak dan mendapat pendidikan awal di Tanah Melayu dan Sumatera sebelum menyambung pengajian dalam bidang Homeopathy dan Falsafah di Aligarh University, India pada akhir tahun 1920-an. Beliau pernah melawat Palestin dan menjadi ahli pertubuhan sukarela yang membela nasib rakyat Palestin dan kembali ke Tanah Melayu pada tahun 1936. Beliau pernah dilantik sebagai Penasihat Hal Ehwal Adat dan Agama Islam di Taiping ketika pendudukan Jepun. Selepas Perang Dunia Kedua, beliau terlibat dalam kegiatan Parti Kebangsaan Melayu Malaya (PKMM) dan bekerjasama dengan All-Malaya-Council of Joint Action (AMCJA). Beliau kemudian dilantik sebagai Presiden PAS pada tahun 1956. Beliau telah ditahan oleh kerajaan Malaysia pada tahun 1965 kerana disyaki membantu Indonesia dalam Konfrontasi Malaysia-Indonesia, sebelum dibebaskan lima tahun kemudian kerana sakit batu karang yang kronik. Lihat Ramlah Adam, Sumbanganmu Dikenang, Kuala Lumpur: Dewan Bahasa dan Pustaka, 2002, hlm. 124-153. Untuk maklumat lanjut tentang Dr. Burhanuddin al-Helmy, lihat Ramlah Adam, Burhanuddin al-Helmy: Suatu Kemelut Politik, Kuala Lumpur: Dewan Bahasa dan Pustaka, 1996. SP 142/9, Warta Persekutuan Melayu Mesir, Jil. 1, Bil. 8, 15 Ogos 1962, hlm. 3. Ishak Haji Muhammad (1909-1991) atau Pak Sako dilahirkan di Kampung Segentang, Temerloh, Pahang. Beliau mendapat pendidikan awal di Sekolah Melayu pada tahun 1919. Pada tahun 1924, beliau memasuki Sekolah Inggeris di Kuala Lipis seterusnya menyambung pengajian di Maktab Melayu Kuala Kangsar, Perak. Selepas menamatkan pengajian, beliau berkhidmat sebagai pegawai dan majistret dalam Malay Administrative Services (MAS). Beliau kemudian meninggal jawatan sebagai majistret dan berhijrah ke Kelantan dan Johor seterusnya ke Singapura untuk berkhidmat sebagai wartawan akhbar. Pada tahun 1937, beliau telah menerbitkan dua buah buku iaitu Putera Gunung Tahan dan Anak Mat Lela Gila. Beliau kemudian menyertai Kesatuan Melayu Muda (KMM) dan pernah dipenjarakan oleh British ketika pendudukan Jepun. Beliau pernah menyertai PKMM dan pernah memimpin Parti Buruh Malaya dan Front Sosialis. Lihat Mustapha Hussain, Malay Nationalism before UMNO: The Memoirs of Mustapha Hussain, Kuala Lumpur: Utusan Publications and Distributors Sdn. Bhd., 2005, hlm. 155-157. Untuk maklumat lanjut tentang Ishak Haji Muhammad, lihat Abdul Latiff Abu Bakar, Ishak Haji Muhammad: Penulis dan Ahli Politik Sehingga 1948, Kuala Lumpur: Penerbit Universiti Malaya, 1977.

103 SP 142/9, Warta Persekutuan Melayu Mesir, Jil. 1, Bil. 15, 1 Disember 1962, hlm. 3. Ketika itu Kassim Ahmad dalam perjalanan ke London setelah ditawarkan untuk mengajar bahasa dan sastera Melayu di School of Oriental and African Studies (SOAS), University of London. Sekembalinya ke tanah air pada tahun 1966, beliau telah dilantik sebagai Pengerusi Parti Sosialis Rakyat Malaysia (PSRM). Kerajaan yang bimbang dengan pengaruh sosialisme yang semakin berkembang bertindak menangkap beliau dan anggota PSRM pada tahun 1976. Lihat Kassim Ahmad, Mencari Jalan Pulang: 
Daripada Sosialisme Kepada Islam, Petaling Jaya: ZI Publications Sdn. Bhd., 2008, hlm. 101 \& 173; Meredith L. Weiss, Protest and Possibilities: Civil Society and Coalitions for Political Change in Malaysia, California: Stanford University Press, 2006, hlm. 99.

104 Lima wilayah yang dimaksudkan ialah Tanah Melayu, Sabah, Sarawak, Singapura dan Brunei. Terdapat perdebatan yang hebat berkenaan pemilihan nama baru bagi gabungan tersebut iaitu sama ada nama "Melayu Raya" atau "Malaysia". Laporan Suruhanjaya Cobbold menyatakan bahawa penduduk Sarawak dan Borneo Utara lebih bersetuju dengan nama Malaysia. Lihat "Bapa Melayu Raya", The Straits Times, 23 August 1962, hlm. 1. Meskipun Pemuda UMNO lebih bersetuju dengan nama "Melayu Raya", namun Tunku Abdul Rahman pula lebih bersetuju dengan nama "Malaysia". Lihat "It's Set: 'Bapa Malaysia", The Straits Times, 24 August 1962, hlm. 1. SP 142/9, Warta Persekutuan Melayu Mesir, Jil. 1, Bil. 9, 1 September 1962, hlm. 1.

106 Osman Ralibi merupakan anak seorang hartawan yang berasal dari Sigil, Acheh dan tinggal di Singapura. Beliau telah menyambung pengajian dalam bidang perundangan di Universiti al-Azhar selama tiga tahun, seterusnya pulang ke Singapura. Pada peringkat awal, beliau berhasrat untuk melanjutkan pelajaran di England, namun ayahnya mengambil keputusan untuk menghantar beliau ke Kaherah. Lihat "Egypt Completely Pro-British", The Singapore Free Press and Mercantile Advertiser, 26 July 1940, hlm. 7.

Presiden Gamal Abdel Nasser kemudian telah menyatakan persetujuan untuk memberikan sebidang tanah di Madinah al-Nasr kepada PMM. Beliau juga telah menandatangani dekri berkenaan pemberian tanah tersebut kepada PMM dengan kadar sewa hanya $£ 1$ (Mesir) setahun. Lihat Wan Mokhtar Ahmad, Muzakkirah: Sebuah Autobiografi Suku Abad Menerajui Kerajaan Terengganu, Kuala Lumpur: Utusan Publications \& Distributors Sdn. Bhd., 2008, hlm. 21-22. SP 142/9, Warta Persekutuan Melayu Mesir, Jil. 1, Bil. 2, 1 Mac 1962, hlm. 1.

109 Perhimpunan tersebut dihadiri oleh hampir 600 pelajar Melayu. Sehingga tahun 1952, Perhimpunan Agong Persekutuan Pelajar Melayu Tanah Melayu (PPMTM) mewakili 14 pertubuhan pelajar Melayu dengan jumlah keanggotaan mencecah 4,000 orang ahli. Lihat "Student Told: Don't Indulge in Politics", The Straits Times, 27 December 1952, hlm. 7. 